\title{
Asian American and Pacific Islander Wealth Inequality and Developing Paths to Financial Security
}

\author{
C. Aujean Lee, Lisa Hasegawa, \\ Melany De La Cruz-Viesca, and Paul M. Ong
}

The increasing racial wealth gap in the United States is a troublesome sign that millions of families nationwide do not have enough in assets for future needs, such as home purchases, secondary education for children, a financial buffer in periods of uncertainty, and retirement. Additionally, many families face challenges with earning enough income to afford necessities such as housing, food, transportation, and medical care. It is important to note that wealth and income are quite different and should not be used interchangeably. This special issue of the Asian American Pacific Islander Nexus Journal focuses on wealththe accumulation of all your assets, both physical and financial investments. In particular, why wealth is what really matters and is as important as income in better understanding economic inequality.

This special issue is also the first publication devoted entirely to an in-depth examination of Asian Americans and Pacific Islanders (AAPIs), Native Hawaiians, and wealth. While previous work may have included a chapter on the issue (e.g., see Ong and Patraporn, 2006), this special journal issue gives voice to the highly diverse and complex AAPI population's ideals, concerns, and priorities in relation to wealth inequality and financial security and moves beyond the simplistic and misleading "model minority" stereotype. The special issue is a collection of papers presenting new insights that can enrich the policy debates on tax policy reform, financial capability, student loans, social security, retirement, housing, small business, and additional asset-building issues, especially how they relate to other communities of color.

More than ever, it is important to include AAPIs in the development of a more inclusive, fair, and comprehensive narrative about racial 
inequality. Nearly all research on wealth and assets look at the factor of race and the measurable impacts of structural racism. We know that institutional and structural racism is fueled by anti-blackness and that AAPIs are used as a wedge in the racial wealth gap debate. These studies on the racial wealth divide either exclude AAPIs (often rendering them invisible) or lump all forty or more ethnic groups into an aggregate category of AAPIs and frame them as doing as well as or better than white communities or the general population. This reduction of the discourse to simply race also obscures systematic ethnic disparities among AAPIs. By ignoring ethnic group differences, we fail to acknowledge the wealth barriers that many groups experience, and are consequently left out of asset-building policies and programs.

This default framing of AAPIs undermines the notion that race and ethnicity matters and weakens the arguments for structural racism and financial justice for communities of color. Perhaps unintended, but the very dangerous subtext and implication is if AAPI communities can overcome barriers associated with race or racism, why can't other communities of color do the same? The inclusion of diverse AAPI voices and better AAPI data will strengthen efforts to dismantle structural racial inequality, not undermine them. With this special issue, we demonstrate that race and ethnicity does indeed matter in developing the narrative on wealth inequality and it is the lack of better data for AAPIs and more nuanced analysis that contributes to a deceiving narrative.

AAPIs have faced historic discrimination-from the stereotype of the perpetual foreigner that created the segregated Chinatowns, to the wealth stripping of Japanese Americans during World War II when they had to sell or abandon homes, treasured belongings, businesses, and land. Today, AAPIs continue to face discrimination in a multitude of ways, for example manifested in the form of accent discrimination, such as lack of equal access to services due to language barriers in health, employment, and housing. These are influencing factors that exacerbate wealth inequalities. In contrast, the analysis of AAPI data must look at the generational composition of a household and immigration status. For example, how U.S. immigration policy privileges and grants citizenship to those who have high wealth holdings in their countries of origin that could be invested in America. Thus, complicating our understanding of the wealth position for Asians born in the United States compared with foreign-born Asians.

In the few studies that examine Native Hawaiians and Pacific Islanders by ethnic group, researchers have also found these groups 
lagging behind others. For example, Naya (2005) found that Native Hawaiians had lower interest, dividends, and rental income in addition to public assistance, retirement, social security, and supplementary security income than non-Native Hawaiians in Hawai'i. Ong (2006) also examined farmland assets owned by Native Hawaiians in Hawai'i, and found that a majority of the land is owned by whites (or about 75 percent); by contrast, Native Hawaiians owned less than 5 percent in 2002. Native Hawaiians also have much lower average income from assets in Hawai' $i$ - on average, they have about $\$ 2,000$ in asset income compared to whites who on average have $\$ 8,430$ in assets (ibid.).

Moreover, AAPI ethnic groups must be oversampled to ensure that there is enough statistical power for meaningful analysis. Recently, two federal agencies announced encouraging policy developments related to AAPI data. The Consumer Financial Protection Bureau and the U.S. Department of Housing and Urban Development both announced in late 2015 that they will be collecting disaggregated AAPI subpopulation data for two major federal data sets-the American Housing Survey and Home Mortgage Disclosure Act. Furthermore, there has been some progress with major institutions such as the Federal Reserve Board of Governors and the Ford Foundation taking into serious consideration that the AAPI perspective is indispensable when discussing income and wealth disparities.

AAPI Nexus is deliberately dedicated to crossing boundaries between academic researchers, community practitioners, and policy makers. We are proud to present the first publication of research articles, practitioner essays, and resource papers that represent the best emerging research and knowledge focused on Asian Americans, Pacific Islanders, Native Hawaiians, and wealth. The articles in this special issue are organized into three themes: intersections of wealth and financial capability; housing and financial justice; and policy interventions and community-based responses.

\section{Intersections of Wealth and Financial Capability}

This section includes information about new data sets that address the lack of data on wealth and financial holdings in federal surveys such as the U.S. Census, in particular for AAPIs. The articles also focus on financial stability over the life cycle, including analysis on youth, college students, and older adults. The topics in this section touch on the following areas: reframing the Asian American wealth narrative with new data from the National Asset Scorecard for Communities of Color 
Survey; Pacific Islanders and financial distress; financial access, attitudes, and behaviors of low- and moderate-income AAPIs; increasing youth financial capability through an examination of AAPI participants in the MyPath Savings Initiative; perspectives from AAPI community college students; and the financial security of AAPIs age fifty and older.

\section{Housing and Financial Justice}

The next theme, housing and financial justice, provides an overview of housing as an important asset and the context for what has happened to AAPIs, particularly with the Great Recession. As the articles note, housing is critical to financial security and wealth accumulation because it is the largest single source of wealth for AAPIs. These articles provide a nuanced understanding of AAPIs and housing, particularly as related to home ownership, housing burden, foreclosures, and institutions that support housing, including banks and housing counseling agencies (HCAs). The foci in this section examine diversity and disparity in home equity among Asian Americans; Asian American home ownership and foreclosure pre- and posthousing boom in east San Gabriel Valley, California; AAPI foreclosure rates in Orlando, Florida, and Phoenix, Arizona; the role of Asian-owned banks in access to credit in Los Angeles and New York; and segmentation and devolution among Asian American-serving HCAs and other HCAs that do not serve a specific target population in Minneapolis-St. Paul, Minnesota, region.

\section{Policy Interventions and Community-Based Responses}

This special issue would not be complete without the perspectives of policy advocates and community practitioners, who offer great insights, new and innovative ideas, and solutions as to how to increase financial security for AAPIs. The papers in this section address the U.S. tax code and how it favors the wealthiest of Americans and expands the racial-wealth gap; the National Coalition for Asian Pacific American Community Development's Immigration Integration Financial Capability project-a pilot project in Chicago, Houston, Los Angeles, and New York; and participatory research and cooperative economic strategies with South Asian immigrant women in the Bronx. The policies and programs discussed in these articles offer additional insights regarding how to build AAPI financial capability and security, either through macrolevel federal tax codes or through locally based programs that integrate financial services with other social services. Particularly because community-based organizations are key institutions 
that oftentimes provide a one-stop shop for clients, they need to better incorporate asset-building services in the institution as a whole to reach a broader audience.

\section{Complementary Policy Topics}

This issue also includes two nontheme papers that address complementary policy topics that are important for AAPI data collection and presentation - the potential for data disaggregation to resolve blind spots in policy making for Native Hawaiians and other populations and the importance of how to frame data on Asian Americans. The themes discussed throughout the special issue reflect the fundamental tenets of financial justice, with each article reflecting upon careful, evidencebased consideration of issues with precise application to AAPI groups.

\section{Implications for Future Research}

While these articles do help to address gaps in the literature, we acknowledge there is more research and work to be done. We also need more information about broader age groups. While we do include some information on AAPI youth and older adults, we are still lacking knowledge about child savings accounts and older adults in relation to social security and retirement. In particular, we have inadequate knowledge about the wealth position of AAPI older adults with limited assets or loss of employment during the recession. The special issue also does not include information on small businesses and how they contribute or hinder wealth building. Studies have shown that many Asian immigrants have higher rates of self-employment because of the language barrier (Bates, 1999).

We also need to broaden how transnational ties have impacted assets. Transnational capital is nothing new, particularly because of the importance of remittances for many AAPIs. For example, National Council of La Raza (2014) found that about 22 percent of AAPI low- and moderate-income survey respondents used remittances or wire transfer — a rate slightly higher than Latinos (17 percent)—and also the third most used alternative financial service, following a credit card from a bank and a gift card. Also, there are some studies that have shown that Tonga, Samoa, and Fiji are dependent on remittances, where family members are identified to work abroad so as to increase economic returns for the family (Brown, Connell, and Jiminez-Soto, 2014). However, there are few studies that focus on how remitters in America are impacted in their ability to build assets either in the United States or 
abroad. Along with remittances, U.S. immigration laws currently favor international investors. As a result, there has been a significant increase in the number of Asian investors purchasing homes and businesses in the United States. More research is necessary to comprehend how these laws provide strategies for asset building.

According to the U.S. Census Bureau, the number of Asian Americans will increase 74 percent from 20.5 million in 2015 to 35.7 million in 2040, making Asian Americans the fastest-growing racial population in the nation (Ong, Ong, and Ong, 2015). The Native Hawaiian and Other Pacific Islander population is projected to increase 63 percent from 1.5 million in 2014 to 2.9 million in 2060 (Colby and Ortman, 2015). The most recent data from the U.S. Census Bureau confirm that in 2009, for the first time since this annual data series has been released, less than one-half of all the three-year-old children were white (U.S. Census Bureau, 2010). This racial and ethnic shift will be even greater over the next several decades, as the Asian population is expected to nearly double to constitute 9 percent of the population and Latinos are expected to double and become 29 percent of the total population by mid-century (ibid.). An increasingly diverse population will continue to affect every aspect of U.S. society and could have a significant influence on the political and economic state. The impact of growing communities of color is on par, or potentially even greater than the impact baby boomers have had on American business, consumerism, and culture. Consequently, as we continue to live in an increasingly interconnected and interdependent global economy, closing the racial wealth gap is critical to growing the U.S. economy and financial stability. By improving the assets and wealth position of immigrants and communities of color, the United States as a whole will foster greater economic security.

Previous research, including that supported by the Ford Foundation, Federal Reserve, and others, has revealed disparities by ethnicity and nativity, but the literature on AAPIs is still rather limited because of very little disaggregated wealth data and analysis. This collection of essays will add to the cumulative body of knowledge on wealth and financial security and serve as a foundation for future research.

\section{Acknowledgments}

We are grateful for the support provided by the UCLA Asian American Studies Center, the UCLA Center for the Study of Inequality, and the National Coalition for Asian Pacific American Community Development. This special issue is made possible by the generous contribu- 
tion and support of the Ford Foundation's Building Economic Security over a Lifetime Initiative. ${ }^{1}$ We want to especially acknowledge our Ford Foundation Program Officers-Kilolo Kijakazi and Amy Brown. We are also thankful for the editorial and administrative support of Andrea Truong and Jenny Chhea.

\section{Note}

1. The Ford Foundation's work is on the development and maintenance of permanent social protection programs that can create financial assets that break the intergenerational cycle of poverty. In the United States, the Ford Foundation's Building Economic Security over a Lifetime initiative promotes public support for policies that create universal and progressive savings accounts as well as Social Security and pension reforms that increase benefits for low-wage workers. For more information, please visit the foundation's website at http: / / www.fordfoundation.org/issues / economic-fairness/building-economic-security-over-a-lifetime.

\section{References}

Bates, Timothy. 1999. "Exiting Self-Employment: An Analysis of Asian Immigrant-Owned Small Business." Small Business Economics, 13(3): 171-83.

Brown, Richard P. C., John Connell, and Eliana V. Jimenez-Soto. 2014. "Migrants' Remittances, Poverty and Social Protection in the South Pacific: Fiji and Tonga." Population, Space and Place, 20(5): 434-454.

Colby, Sandra L. and Jennifer M. Ortman 2015. "Projections of the Size and Composition of the U.S. Population: 2014 to 2060." U.S. Census Bureau Current Population Reports. https://www.census.gov/content/dam/Census/ library / publications / 2015/demo/p25-1143.pdf (accessed April 17, 2015).

National Council of La Raza with National Coalition for Asian Pacific American Community Development, and National Urban League. 2014. "Banking in Color: New Findings in Financial Access for Low- and Moderate-Income Communities." Washington, DC: National Council of La Raza

Naya, Seiji. 2005. Income Distribution and Poverty Alleviation for the Native Hawaiian Community. Working Paper No. 91. Honolulu, HI: East-West Center.

Ong, Paul. 2006. "Trouble in Paradise: The Economic Marginalization of Native Hawaiians." Pp. 155-72 in Wealth Accumulation and Communities of Color in the United States: Current Issues, ed. J. G. Nembhard and N. Chiteji. Ann Arbor: University of Michigan Press.

Ong, Paul, and R. Varisa Patraporn. 2006. "Asian Americans and Wealth." Pp. 173-90 in Wealth Accumulation and Communities of Color in the United States: Current Issues, ed. J. G. Nembhard and N. Chiteji. Ann Arbor: University of Michigan Press.

Ong, Paul, Jonathan Ong, and Elena Ong. 2015. "The Future of Asian America in 2040." UCLA Center for the Study of Inequality and Asian Pacific American Institute for Congressional Studies. Los Angeles, California. 
U.S. Census Bureau. 2010. “Facts for Features: Asian/Pacific American Heritage Month." http:/ / www.census.gov/newsroom/releases/archives/facts_for_ features_special_editions/cb11-ff06.html (accessed February 7, 2015).

C. Aujean Lee is a doctoral student at the University of California, Los Angeles. She received her M.U.P. from the University of Illinois at Urbana-Champaign and her B. A. from the University of California, Los Angeles.

Lisa Hasegawa is the executive director of the National Coalition for Asian Pacific American Community Development (National CAPACD). She has devoted her life to improving the quality of life for low-income AAPI communities by promoting economic vitality, civic and political participation, and racial equity. Through her leadership with the National Council of Asian Pacific Americans, she has strengthened the overall relevance of AAPIs in housing and economic justice. She currently serves on the boards of the National Low Income Housing Coalition and Local Initiatives Support Corporation. Lisa is a fourth generation Japanese American from California, and is a graduate of the University of California, Los Angeles, and the Harvard School of Public Health.

Melany De La CRUZ-Viesca is the assistant director of the UCLA Asian American Studies Center and managing editor of Asian American Pacific Islander Nexus: Policy, Practice and Community, a nationwide journal focusing on AAPIs, policy, practice, and community issues. She also directs the AAPI Community Development Census Information Center. Her research focuses on Asian American, Native Hawaiian, and Pacific Islander demographics and policy, in relation to asset building, wealth inequality, housing, community economic development, and education. She holds a master's degree in urban planning from UCLA and a bachelor's degree in ethnic studies and urban studies and planning from UC San Diego.

Paul M. Ong is a professor at UCLA's Luskin School of Public Affairs and UCLA's Asian American Studies Department. He is currently the Director of the UCLA Center for the Study of Inequality, founding editor of AAPI Nexus: Policy, Practice and Community, and founding director of the UC AAPI Policy Multi-Campus Research Program. He has conducted research on immigration, civic and political participation, economic status of minorities, welfare-to-work, health workers, urban spatial inequality, and environmental inequality. 